\title{
An Invitation to Visit Your Saskatchewan Museum of Natural History
}

\author{
Fred G. Bard, Director
}

The Museum of Natural History under Conservation Education operates as a Branch of the Department of Natural Resources.

The purpose of the Museum from its beginning was to exhibit the birds and mammals of Saskatchewan. In 1912 the cyclone destroyed a considerable portion of the collection. In 1913 the first full time Preparator, Mr. H. H. Mitchell was engaged to collect and prepare the birds and mammals. Each Spring a field camp was selected to collect representative specimens, these sites varied each year to give reasonable Province wide coverage. Usually each Spring a "first" or new bird record turned up and by 1924 Mitchell published the "Catalogue of the Birds of Saskatchewan." The last new record was a Yellow-throated Vireo taken by F. W. Lahrman at Madge Lake in 1951.

Field camps are expanded from faunal collecting to include some activity in Archaeological excavations to and including the Fur Trading Post era; Paleontological excavations are carried out in the Eastend area. These last two activities are an acknowledgement of our responsibility for collecting and preserving such material to form the nucleus for future research.

Mr. Fred Bradshaw was the first Museum Director (1928-1935) and visited the country schools giving illustrated lectures. These iectures stressed the value of wildlife and the need for conservation. Mr. F. A. Dunk served the Province as Museum Director from 1935-1947. In tnis period our most serious drought hit, and with the great decline in the waterfowl population, conservation programs were active. These two men were active in conservation programs. For as long as I can remember the Museum has always advocated coriservation of our Wildife Resources.

Our bird collection is one of the most complete. It numbers over three hundred varieties all within our provincial boundaries-besides the cases that house separate bird families we have habitat group cases, each includes the male, female, eggs or young. While some are small cases, for example the Yellowthroat: the newest are 12 feet long and include several species of birds and animals to illustrate those living in close association. The latter is more natural--no species lives isolated.

We are beginning seven more 12foot habitat groups. The cases are complete, Mr. Swanston and Mr. Walker are building the portable backgrounds. These cases will depict such groups as the Whooping Crane, Otosquen Ecological group, Timber Wolves, Beaver, Pelicans of Last Mountain, Ring-billed Gulls and Coyote. There completion will take several seasons. Seven cases were started to build an island of groups. These cases are not permanent, that is, they can be moved when suitable quarters are available. More permanent foregrounds can be made when the museum is permanently housed.

More recently we have moved into the field of motion pictures and our first film the "Pelicans of Last Mountain" is currently being distributed. We are confident the Museum will continue to play an important part in having our citizens of the Province better understand and appreciate our Wildlife resources to reserve sanctuaries for this heritage for generations yet to come.

We invite you to visit your "Saskatchewan Museum of $\mathrm{N}$ at u ral History" located at College and Broad Street in the Provincial Health Building, Regina.

The "Summer Season" open hours are 8.30-5 o'clock weekdays; 2-5 o'clock Saturdays and Sundays-May to October.

The "Winter Season" open hours are 9-5 o'clock weekdays; Saturdays 9-12 o'clock and Sundays 2-5 o'clock during November to April. The Museum is closed on all holidays. This is an invitation to visit your Museum of Natural History. 